\title{
EVALUASI PENGGUNAAN DANA DESA TAHUN 2015 PADA BADAN PEMBERDAYAAN MASYARAKAT KAMPUNG DAN TRANSMIGRASI (BPMKT) KABUPATEN KEPULAUAN YAPEN,PAPUA
}

\author{
Olana Christin Pasodung ${ }^{1}$, Jantje J. Tinangon ${ }^{2}$ \\ ${ }^{1}$ Pendidikan Profesi Akuntansi, Fakultas Ekonomi dan Bisnis, Universitas Sam Ratulangi, J1. Kampus Bahu, \\ Manado, 95115, Indonesia \\ ${ }^{2}$ Jurusan Akuntansi, Fakultas Ekonomi dan Bisnis, Universitas Sam Ratulangi, Jl. Kampus Bahu, Manado, \\ 95115, Indonesia \\ E-mail : pasodunglana@gmail.com
}

\begin{abstract}
For the welfare of the nation, the Government is determined to build Indonesia from the periphery to strengthen these areas and villages within the framework of the Unitary Republic of Indonesia. Indonesia build on the outskirts of the village it means to be constructed because the majority of the Indonesian population is no village. So, in building the village there are some things that need to be noticed, especially in the aspect of management / use of village funds, namely, the village fund should be used properly so that tangible results in the field can be seen according to the Government Work Plan Kampung (RKPK) that apply to each each village / villages in the district Yapen islands. In Serui are still many villagers whose lives have not been feasible. This means that the use of village funds in some villages, there penyelewangan funds in the field that are not in accordance with RKPK and legislation in force in Indonesia. Thus the need for regulatory oversight remained in the village fund management process to avoid abuses that occurred while in the field. This study aims to determine the use of funds Yapen Islands district villages in Papua has been run with the maximum or not according to the rules applicable legislation. Research type used is descriptive research including data collection form of description of the distribution process, management / use, supervision until accountability applied by the village fund 160 villages in Serui. Research on Community Empowerment Board Kampung and Transmigration (BPMKT) Yapen Islands is there are still many shortcomings in the village in a few villages in the use of funds of the village so the concrete manifestation of the results of the field went wrong RKPK and forms of accountability of the use of village funds have not been implemented in a timely manner. Thus the need for regulation that is still to organize activities to be undertaken by the villagers.
\end{abstract}

Keywords: the use of village funds, Village Community Empowerment Board and Transmigration.

\section{PENDAHULUAN}

Visi trisakti Presiden Republik Indonesia periode tahun 2014-2019 meletakan program pemerintah pada titik berat pencapaian ideal bangsa indonesia pada kedaulatan politik, kemandirian ekonomi, dan kepribadian budaya. Membangun Indonesia dari pinggiran itu berarti desa harus dibangun karena sebagian besar penduduk Indonesia ada didesa. masyarakat desa harus diposisikan sebagai subjek atau pelaku dari pembangunan itu sendiri, sehingga masyarakat desa diberi kewenangan untuk dapat mendefenisikan kebutuhannya sendiri sehingga program dan kegiatan pembangunan desa betul-betul menyentuh secara langsung kebutuhan masyarakat desa. Di Kabupaten Kepulauan Yapen Provinsi Papua masih terdapat desa-desa (di Papua, desa disebut dengan nama lain yaitu Kampung) dan masih banyak yang terpencil/terisolasi sehingga dikategorikan sebagai daerah tertinggal, maka 
kebijakan pemerintah dengan penyediaan dana desa merupakan peluang yang harus ditangkap dan dimanfaatkan dalam pembangunan kampung khususnya bidang pemberdayaan masyarakat kampung. Dana Desa sebagai dana pemberdayaan masyarakat yang ditransfer dari RKUN ke RKUD dan selanjutnya kerekening kampung pada tingkat kabupaten dalam mekanisme pengelolaannya sesuai dengan ketentuan dan peraturan yang ada ditangani oleh Badan Pemberdayaan Masyarakat Kampung dan Transmigrasi (BPMKT) Kabupaten Kepulauan Yapen. Sehingga atas dasar pemikiran inilah maka penelitian ini mengambil topik "Evaluasi Penggunaan Dana Desa Tahun 2015 Pada Badan Pemberdayaan Masyarakat Kampung dan Transmigrasi Kabupaten Kepulauan Yapen,Papua”.

\section{TINJAUAN PUSTAKA}

\subsection{Pemerintah Desa}

Pemerintah Desa merupakan lembaga perpanjangan pemerintah pusat yang memiliki peran strategis untuk mengatur masyarakat yang ada di pedesaan demi mewujudkan pembangunan pemerintah. Berdasarkan perannya tersebut, maka diterbitkanlah Peraturanperaturan atau Undang-Undang yang berkaitan dengan pemerintah desa yang mengatur tentang pemerintah desa, sehingga roda pemerintahan berjalan dengan optimal.

\subsection{Sumber dan Pembatasan Penggunaan Dana Transfer}

Berdasar suumber dan pembatasan dalam penggunaannya, dana ditransfer menjadi dana bagi hasil, dana alokasi umum, dan dana transfer khusus.

\subsection{Keuangan Desa}

Keuangan desa adalah semua hak dan kewajiban dalam bentuk satuan uang, serta segala sesuatu baik berupa uang maupun barang yang dapat menjadi milik desa. Keuangan desa tersebut terdiri atas: Pendapatan, dan Belanja desa.

\subsection{Peran Kerangka Konseptual Akuntansi Sektor Publik}

Posisi kerangka konseptual ini sebagai landasan konsep, baik untuk penetapan standar akuntansi maupun praktek akuntansi maka setidak-tidaknya suatu kerangka konseptual harus merumuskan : (1) tujuan akuntansi secara jelas; (2) karakteristik-karakteristik kualitatif informasi bermanfaat; (3) definisi, pengakuan dan pengukuran unsur-unsur laporan keuangan; dan (4) konsep-konsep mendasar dalam akuntansi.

\subsection{Praktek Teori Agensi Pada Entitas Sektor Publik}

Kemitraan yang dimaksud dalam UU tersebut bukanlah kemitraan yang sepenuhnya sejajar. Dalam literatur ilmiah, baik dalam disiplin ekonomi (termasuk akuntansi), politik, maupun keuangan, hubungan seperti ini disebut hubungan keagenan.

\subsection{Hubungan Keagenan dalam Penyusunan Anggaran Daerah di Indonesia}

Anggaran daerah merupakan rencana keuangan yang menjadi dasar dalam pelaksanaan pelayanan publik. Di indonesia dokumen anggaran daerah disebut anggaran pendapatan dan belanja daerah (APBD), baik untuk provinsi maupun kabupaten dan kota. Proses penyusunan anggaran pasca UU 22/1999 (dan UU 32/2004) melibatkan dua pihak: eksekutif dan legislatif, masing-masing melalui sebuah tim atau panitia anggaran.

\subsection{Dampak Teori Agensi Pada Kinerja Entitas Secara Keseluruhan}

Hubungan agensi ini memotivasi setiap individu untuk memperoleh sasaran yang harmonis dan menjaga kepentingan masing-masing antara agen dan principal.

\subsection{Undang-Undang No.6 Tahun 2014 Tentang Desa}

Penyelenggaraan Pemerintahan Desa berdasarkan asas: a.kepastian hukum; b. Tertib penyelenggaraan pemerintah; c.tertib kepentingan umum; d.keterbukaan; e.proporsionalitas; f.profesionalitas; g.akuntabilitas; h.efektivitas dan efisiensi; i.kearifan lokal; j.keberagaman; dan k.partisipatif. 


\subsection{Peraturan Pemerintah No.60 Tahun 2014 Tentang Dana Desa Yang Bersumber Dari Anggaran Pendapatan dan Belanja Negara}

Dana Desa digunakan untuk membiayai penyelenggaraan pemerintahan, pembangunan, pemberdayaan masyarakat, dan kemasyarakatan.

2.10. Peraturan Menteri Desa No.5 Tahun 2015 Tentang Penetapan Prioritas Penggunaan Dana Desa Tahun 2015

Prioritas penggunaan Dana Desa untuk pembangunan Desa dialokasikan untuk mencapai tujuan pembangunan Desa yaitu meningkatkan kesejahteraan masyarakat Desa dan kualitas hidup manusia serta penanggulangan kemiskinan, melalui pemenuhan kebutuhan dasar; pembangunan sarana dan prasarana Desa; pengembangan potensi ekonomi lokal; dan pemanfaatan sumber daya alam dan lingkungan secara berkelanjutan.

2.11. Keputusan Bersama Menteri Dalam Negeri, Menteri Keuangan, dan Menteri Desa, Pembangunan Daerah Tertinggal dan Transmigrasi No.49 Tahun 2015 Tentang Percepatan Penyaluran, Pengelolaan, dan Penggunan Dana Desa Tahun 2015

1. Menteri Desa, Pembangunan Daerah Tertinggal dan Transmigrasi memfasilitasi percepatan penggunaan Dana Desa Tahun 2015 untuk kegiatan-kegiatan yang dijelaskan pada program-program di permendes nomor 5 tahun 2015.

2. Menteri Desa, Pembangunan Daerah Tertinggal dan Transmigrasi melakukan percepatan penyediaan tenaga pendamping desa dan optimalisasi tenaga pendamping desa yang sudah ada.

\subsection{Penelitian Terdahulu}

Tabel.1 Penelitian Terdahulu

\begin{tabular}{|c|c|c|c|c|c|c|}
\hline No & $\begin{array}{l}\text { Nama } \\
\text { /Tahun }\end{array}$ & Judul & Metode & Hasil & Persamaan & Perbedaan \\
\hline 1. & $\begin{array}{l}\text { Agus } \\
\text { Subroto } \\
\text { (2009) }\end{array}$ & $\begin{array}{c}\text { Akuntabilitas } \\
\text { Pengelolaan } \\
\text { Dana Desa }\end{array}$ & $\begin{array}{l}\text { Metode } \\
\text { penelitian } \\
\text { yang } \\
\text { dipakai } \\
\text { adalah } \\
\text { deskripsif } \\
\text { kualitatif. }\end{array}$ & $\begin{array}{l}\text { Hasil dari } \\
\text { Penelitian ini } \\
\text { adalah } \\
\text { Pertanggung } \\
\text { jawaban ADD } \\
\text { baik secara } \\
\text { teknis maupun } \\
\text { administrasi } \\
\text { sudah baik, } \\
\text { namun dalam } \\
\text { hal } \\
\text { pertanggung } \\
\text { jawaban } \\
\text { administrasi } \\
\text { keuangan } \\
\text { kompensasi } \\
\text { SDM } \\
\text { pengelola } \\
\text { merupakan } \\
\text { kendala } \\
\text { utama. }\end{array}$ & $\begin{array}{l}\text { Persamaan } \\
\text { dari peneliti } \\
\text { sebelumnya } \\
\text { yaitu } \\
\text { melakukan } \\
\text { penelitian } \\
\text { terhadap } \\
\text { dana desa } \\
\text { pada suatu } \\
\text { kabupaten. }\end{array}$ & $\begin{array}{l}\text { Perbedaannya adalah } \\
\text { penulis melakukan } \\
\text { penelitian terhadap } \\
\text { objek yang berbeda } \\
\text { yaitu penulis terdahulu } \\
\text { dengan objek di } \\
\text { Kecamatan } \\
\text { Tlogomulyo } \\
\text { Kabupaten } \\
\text { Temanggung,sedangka } \\
\text { n penulis dengan objek } \\
\text { di Kabupaten } \\
\text { Kepulauan } \\
\text { Yapen,Papua. }\end{array}$ \\
\hline 2. & $\begin{array}{l}\text { Elgia } \\
\text { Hastuti } \\
\text { (2013) }\end{array}$ & $\begin{array}{l}\text { Akuntabilitas } \\
\text { Pemerintah } \\
\text { Desa Dalam } \\
\text { Pengelolaan } \\
\text { Anggaran }\end{array}$ & $\begin{array}{l}\text { Metode } \\
\text { yang } \\
\text { dipakai } \\
\text { dalam } \\
\text { penelitian }\end{array}$ & $\begin{array}{l}\text { Hasil } \\
\text { penelitian ini } \\
\text { yaitu } \\
\text { pelaksanaan } \\
\text { prinsip-prinsip }\end{array}$ & $\begin{array}{l}\text { Persamaan } \\
\text { dengan } \\
\text { Peneliti } \\
\text { sebelumnya } \\
\text { yaitu }\end{array}$ & $\begin{array}{ll}\text { Perbedaannya } & \text { adalah } \\
\text { objek } & \text { peneliti } \\
\text { sebelumnya } & \text { dengan } \\
\text { penulis yaitu } & \text { peneliti } \\
\text { sebelumnya } & \end{array}$ \\
\hline
\end{tabular}




\begin{tabular}{|c|c|c|c|c|c|c|}
\hline No & $\begin{array}{l}\text { Nama } \\
\text { /Tahun }\end{array}$ & Judul & Metode & Hasil & Persamaan & Perbedaan \\
\hline & & $\begin{array}{l}\text { Pendapatan } \\
\text { dan Belanja } \\
\text { Desa } \\
\text { (APBDes) }\end{array}$ & $\begin{array}{l}\text { ini adalah } \\
\text { metode } \\
\text { deskriptif } \\
\text { dengan } \\
\text { pendekata } \\
\text { n } \\
\text { kualitatif. }\end{array}$ & $\begin{array}{l}\text { akuntabilitas } \\
\text { sudah berjalan } \\
\text { baik, namun } \\
\text { masih } \\
\text { memiliki } \\
\text { beberapa } \\
\text { kelemahan. }\end{array}$ & $\begin{array}{l}\text { melakukan } \\
\text { penelitian } \\
\text { terhadap } \\
\text { Anggaran } \\
\text { Dana Desa } \\
\text { apakah telah } \\
\text { sesuai } \\
\text { dengan } \\
\text { peraturan } \\
\text { yang berlaku } \\
\text { atau belum. }\end{array}$ & $\begin{array}{lr}\text { mengambil } & \text { objek di } \\
\text { Desa } & \text { Sareng } \\
\text { Kecamatan } & \text { Geger } \\
\text { Kabupaten } & \text { Madiun } \\
\text { sedangkan } & \text { penulis } \\
\text { mengambil objek pada } & \text { Badan Pemberdayaan } \\
\text { Masyarakat } & \text { Kampung } \\
\text { dan Transmigrasi di } \\
\text { kabupaten kepulauan } \\
\text { Yapen, } & \text { Provinsi } \\
\text { Papua. Serta penulis } \\
\text { mengadakan evalusi } \\
\text { secara keseluruhan } \\
\text { terhadap }\end{array}$ \\
\hline 3. & $\begin{array}{l}\text { Chandr } \\
\text { a } \\
\text { Kusum } \\
\text { a Putra } \\
\text { (2013) }\end{array}$ & $\begin{array}{l}\text { Pengelolaan } \\
\text { Alokasi Dana } \\
\text { Desa Dalam } \\
\text { Pemberdayaa } \\
\text { n Masyarakat } \\
\text { Desa (Studi } \\
\text { Kasus Desa } \\
\text { Wonorejo } \\
\text { Kecamatan } \\
\text { Singosari } \\
\text { Kabupaten } \\
\text { Malang). }\end{array}$ & $\begin{array}{l}\text { Metode } \\
\text { yang } \\
\text { Peneliti } \\
\text { pakai } \\
\text { adalah } \\
\text { metode } \\
\text { deskriptif } \\
\text { dengan } \\
\text { pendekata } \\
\text { n } \\
\text { kualitatif. }\end{array}$ & $\begin{array}{l}\text { Hasil } \\
\text { Penelitian } \\
\text { adalah } \\
\text { menunjukan } \\
\text { bahwa } \\
\text { sebagian dari } \\
\text { dana ADD } \\
\text { untuk } \\
\text { pemberdayaan } \\
\text { masyarakat } \\
\text { digunakan } \\
\text { untuk biaya } \\
\text { operasional } \\
\text { pemerintah } \\
\text { desa dan BPD } \\
\text { sehingga } \\
\text { penggunaan } \\
\text { ADD tidak } \\
\text { sesuai dengan } \\
\text { peruntukanny } \\
\text { a. }\end{array}$ & $\begin{array}{l}\text { Persamaan } \\
\text { dengan } \\
\text { Peneliti } \\
\text { sebelumnya } \\
\text { yaitu } \\
\text { mencari tahu } \\
\text { apakah } \\
\text { penggunaan } \\
\text { Dana Desa } \\
\text { di } \\
\text { realisasikan } \\
\text { sesuai } \\
\text { dengan } \\
\text { rancanganny } \\
\text { a atau tidak. }\end{array}$ & 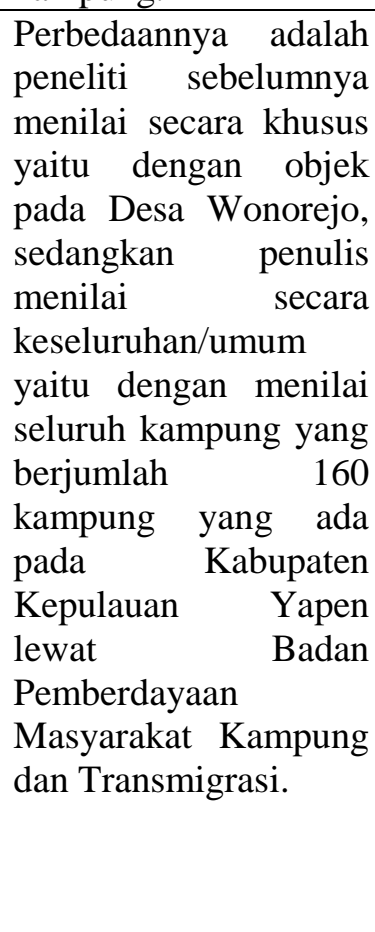 \\
\hline
\end{tabular}

Sumber: Data Olahan Tahun 2016

\section{METODE PENELITIAN}

\subsection{Jenis Penelitian}

Jenis penelitian yang digunakan dalam penelitian ini yaitu jenis penelitian deskriptif adalah pengumpulan data berupa evaluasi aktivitas pengunaan dana desa oleh aparat kampung di kabupaten kepulauan yapen dengan peraturan perundang-undangan yang berlaku berkaitan dengan pengelolaan dana desa. Tipe yang paling umum dari penelitian deskriptif ini meliputi penilaian sikap atau pendapat terhadap individu, organisasi, keadaan, ataupun prosedur (Kuncoro, 2009:12).

\subsection{Tempat dan Waktu Penelitian}

Tempat penelitian dalam menyusun laporan akhir ini adalah Badan Pemberdayaan Masyarakat Kampung dan Transmigrasi (BPMKT) yang beralamat di jalan Maluku, Kabupaten Kepulauan Yapen Papua. 


\subsection{Jenis Data}

Data yang dipakai dalam penelitian ini adalah data kualitatif yaitu data yang berupa uraian penjelasan yang akan di olah dari data yang diperoleh tentang penggunaan dana desa ,fungsi dan tugas Badan Pemberdayaan Masyarakat Kampung dan Transmigrasi di Kabupaten Kepulauan Yapen, dan tata cara penggunaan dana desa yang diterapkan di kepulauan yapen pada BPMKT.

\subsection{Metode Analisis Data}

Metode analisis data yang digunakan adalah metode deskriptif yaitu suatu metode dalam meneliti aktivitias operasional manusia pada suatu objek dengan pemikiran ataupun suatu peristiwa pada masa sekarang, sehingga dapat dilakukan evaluasi penggunaan dana desa berdasarkan peraturan yang berlaku. Tujuan penelitian deskriptif ini adalah membuat deskripsi atau suatu gambaran sistematis, faktual dan akurat tentang fakta-fakta yang berhubungan antar kejadian yang diselidiki.

\section{HASIL ANALISIS DAN PEMBAHASAN}

\subsection{Hasil Penelitian}

Kabupaten Kepulauan Yapen secara geografis terletak di kawasan teluk cendrawasih di provinsi Papua berbatasan sebelah utara dengan kabupaten Biak, sebelah selatan dengan kabupaten Waropen, sebelah timur dengan kabupaten Mamberamo, dan sebelah barat dengan kabupaten Nabire. Kabupaten Kepulauan Yapen mempunyai luas wilayah kurang lebih 7.146,97 yang terdiri dari luas daratan $2.432,485 \mathrm{~km} 2$ dan perairan seluas $4.714,48 \mathrm{~km} 2$ dengan jumlah penduduk sebanyak kurang lebih 152.000 jiwa di tahun 2015. Kabupaten Kepulauan Yapen terdiri dari 16 distrik (kecamatan), 160 kampung, dan 5 kelurahan.

\subsubsection{Mekanisme Penyaluran Dana Desa Di Kepulauan Yapen}

Dana desa yang bersumber dari APBN di transfer dari Rekening Kas Umum Negara (RKUN) ke Rekening Kas Umum Daerah (RKUD) dilakukan dengan syarat : Setiap kabupaten/kota membuat peraturan Bupati/Walikota mengenai tata cara pembagian dan penetapan besaran dana desa, Peraturan Daerah (Perda) tentang Anggaran Pendapatan dan Belanja Daerah kabupaten/kota telah ditetapkan, dan Laporan realisasi penyaluran dan konsolidasi penggunaan dana desa lengkap dan siap dipertanggungjawabkan kepada Pemerintah pusat. Transfer Dana Desa dari RKUN ke RKUD dilakukan secara bertahap pada tahun anggaran berjalan sebagai berikut : Tahap I pada Bulan April sebesar $40 \%$ (empat puluh persen), Tahap II pada bulan Agustus sebesar 40\% (empat puluh persen), Tahap III pada bulan November sebesar $20 \%$ (dua puluh persen). Pasal 100 Peraturan Pemerintah Nomor 47 Tahun 2015 berbunyi Belanja Desa yang ditetapkan dalam APBDes digunakan dengan ketentuan Minimal 70\% (tujuh puluh persen) dari anggaran belanja desa digunakan untuk membiayai penyelenggaraan Pemerintahan Kampung, Pelaksanaan pembangunan Kampung, Pembinaan Kemasyarakatan kampung, dan Pemberdayaan masyarakat Kampung; Minimal $30 \%$ (tiga puluh perseratus) dari jumlah anggaran belanja Desa digunakan untuk: Penghasilan tetap dan tunjangan kepala desa dan perangkat desa, Operasional pemerintah desa; Tunjangan dan Operasional Badan Musyawarah Desa/BPD; Insentif rukun tetangga dan rukun warga;

Setelah Dana Desa berada pada RKUD maka selanjutnya akan di transfer ke rekening kas kampung. Adapun syarat-syarat untuk penyaluran dana desa maka masing-masing kampung harus menyusun sebagai berikut yaitu: RPJMK memuat program dan Kegiatan pembangunan Desa selama kurun waktu 6 (enam) tahun, RAPBK selama satu tahun berjalan, RKPK selama satu tahun berjalan, dan Membuka rekening atas nama rekening kampung. Penggunaan dana desa satu tahun anggaran dipertanggungjawabkan oleh setiap kampung kepada Bupati kepulauan Yapen melalui BPMKT Kabupaten Kepulauan Yapen. Selanjutnya, Bupati membuat laporan konsolidasi dari penggunaan dana desa satu tahun anggaran (tahun 
2015) yang akan disampaikan kepada Kementerian Desa, PDT (Pembangunan Daerah Tertinggal dan Transmigrasi) RI, dimana laporan konsolidasi ini kemudian menjadi salah satu syarat untuk penyaluran dana desa tahun anggaran berikutnya.

\subsection{Pembahasan}

\subsubsection{Kondisi Penggunaan Dana Desa di Kabupaten Kepulauan Yapen}

Pedoman Pelaksanaan dana desa tidak sederhana dan cenderung rumit untuk dipahami dan diimplementasikan oleh masing-masing daerah. Dalam hal mengawasi adanya potensi penyelewengan Dana Desa dari Regulasi, transfer, bahkan peruntukannya. Namun yang terjadi di lapangan berbeda yaitu regulasi yang mengatur pengawasan penggunaan dana desa belum ada petunjuk teknis yang jelas untuk diterapkan pengarahannya oleh pihak yang berwenang mengawasi jalannya kegiatan penggunaan dana desa.

\subsubsection{Evaluasi Penggunaan Dana Desa}

Berdasarkan pemantauan dilapangan penggunaan dana desa di Kabupaten Kepulauan Yapen belum berjalan dengan maksimal sebagaimana yang diharapkan. Data dilapangan menunjukan bahwa dari 160 kampung di kabupaten kepulauan yapen penggunaan dana desa oleh kampung bervariasi ada yang yang telah menggunakan dengan baik, dan ada yang menggunakan tidak sesuai dengan Rencana Kerja kampung, serta ada yang baru mencairkan tahap kedua (tahap ketiga belum). Adapun penggunaan dana desa belum digunakan dengan benar oleh kampung-kampung di kabupaten kepulauan yapen disebabkan oleh beberapa aspek:

\section{Regulasi dan Kelembagaan}

Sebagaimana kita ketahui bahwa program dana desa dimulai dari tahun 2015 dengan sejumlah regulasi yang mengatur pengelolaan keuangan kampung belum lengkap, sehingga regulasi yang sudah ada seiring dengan perjalanan waktu dan kondisi nyata pengelolaan dana kampung dilapangan mengalami perubahan-perubahan dan revisi bahkan ditetapkan regulasi baru sebagai pengganti regulasi sebelumnya. Bahkan potensi tumpang tindih kewenangan kementrian desa PDT dan Transmigrasi Republik Indonesia dan Ditjen Bina Pemerintahan Desa pada Kementrian dalam Negeri RI, menyebabkan para pelaksana ditingkat kabupaten terlebih oleh pengelola ditingkat kampung mengalami kesulitan dan keragu-raguan dalam pengelolaan dana kampung.

\section{Aspek Tata Laksana}

Kerangka waktu siklus/mekanisme penyaluran, pengelolaan/penggunaan dana desa yang sudah diatur sulit dipatuhi, sebagai contoh bahwa transfer dana desa dari pusat ke kabupaten tidak tepat waktu menyebabkan transfer dari kabupaten ke rekening kampung juga mengalami ketidak tepatan waktu yang pada akhirnya berpengaruh pada keterlambatan pelaksana program/kegiatan pembangunan ditingkat kampung, tetapi juga keterlambatan pertanggungjawaban yang dapat mengganggu mekanisme secara keseluruhan. Hal lain belum dikelola dengan baik ditingkat kampung yaitu satuan harga baku, sehingga kampung dalam menyusun Anggaran Pendapatan dan Belanja Kampung APBK belum ada standar harga, menyebabkan standar penyusunan APBK tidak maksimal.

\section{Aspek Pengawasan}

Dari sisi pengawasan penyaluran, pengelolaan/penggunaan dan pertanggungjawaban dana kampung belum ada petunjuk tekhnis/Juknis dan mekanisme baku sebagai pedoman bagi aparat pemeriksa khususnya inspektorat kabupaten dalam melakukan pengawasan dana kampung, sehingga efektivitas inspektorat daerah dalam melakukan pengawasan terhadap pengelolaaan keuangan di kampung belum maksimal disebabkan karena belum ada regulasi yang jelas untuk pengawasan penggunaan dana desa. 


\section{KESIMPULAN DAN SARAN}

\subsection{Kesimpulan}

1. Penyaluran Dana Desa kepada setiap kampung dikabupaten kepulauan yapen pada tahun anggaran 2015 sudah berjalan/ dilaksanakan, namun dalam pengelolaan/penggunaan dan pertanggung jawaban dana desa belum maksimal.

2. Regulasi yang mengatur tentang penyaluran, pengelolaan/penggunaan, pertanggungjawaban dan pengawasan dana desa yang sering berubah-ubah/ direvisi menyebabkan keragu-raguan bagi pelaksana ditingkat kabupaten khususnya ditingkat pemerintahan kampung.

3. Pengelolaan/penggunaan dana desa ditingkat kampung sudah dilaksanakan namun karena sumber daya manusia pengelola sebelumnya tidak dipersiapkan dengan baik, sehingga didalam pelaksanaannya antara rencana kerja/kegiatan dan fakta dilapangan masih ditemui/terdapat ketidak sesuaian.

\subsection{Saran}

1. Sebelum Dana Desa disalurkan ke kabupaten dan selanjutnya ketingkat kampung, maka kepada para pengelola perlu dipersiapkan terlebih dahulu.

2. Regulasi penyaluran, pengelolaan/penggunaan, pertanggungjawaban dan pengawasan dana desa tidak perlu berubah-ubah dan mengalami revisi tetapi perlu disederhanakan dan jelas, sehingga tidak terkesan sulit dan membingungkan sehingga sulit untuk dipatuhi dan diimplementasikan oleh para pengelola khususnya ditingkat kampung. Terlebih juga menyediakan pendamping desa untuk setiap desa.

3. Perlu peningkatan kapasitas sumber daya manusia pengelola dana desa/kampung khususnya bagi aparat pengelola ditingkat kampung seperti pelatihan/diklat, bimbingan teknis (BIMTEK), workshop, dan lain-lain dalam penyusunan RPJMK, RAPBK, dan RKPK serta pengelolaan keuangan kampung dengan baik, penguasaaan teknologi komputer serta ketrampilan lainnya yang mendukung program pembangunan kampung, serta mengajukan syarat untuk Kepala Desa memiliki latar belakang pendidikan yang sesuai.

\section{DAFTAR PUSTAKA}

Andrian, Bayu Berry., 2014. Evaluasi Audit Investigatif Atas Anggaran Dana Desa Oleh Aparat Pengawas Internal Pemerintah Kabupaten Paser (Studi Kasus Temuan Investigasi Di Inspektorat Kabupaten Paser). Tesis Fakultas Ekonomi Universitas Muhammadiyah Malang.

Anindita V. Aulia., 2011. Pemberdayaan Masyarakat Desa Melalui Penerapan Kebijakan Alokasi Dana Desa Kecamatan Bareng Kabupaten Jombang. Skripsi Thesis Universitas Airlangga Surabaya.

Akdhiyanti, Nurul Syaspri., 2015. Strategi Penguatan Patisipasi dan Kapasitas Desa Dalam Pengelolaan Alokasi Dana Desa Di Desa Sekongkang Atas. Institut Pertanian Bogor.

Arifiyanto Dwi Febri., 2014. Akuntabilitas Pengelolaan Alokasi Dana Desa Di Kecamatan Umbulsari Kabupaten Jember Tahun 2012. Skripsi S1 Universitas Jember.

Boonperm Jirawan, dkk., 2012. Appraising the Thailand Villange Fund. The Worldbank Development Research Group: Agriculture and Rural Development Team.

Darmiasih Ni Kadek., 2015. Analisis Mekanisme Penyaluran Alokasi Dana Desa (ADD). Skripsi S1 Fakultas Ekonomi Universitas Pendidikan Ganesha.

Elqorni, Ahmad. 2010. "Mengenal Teori Agen". Diakses Tanggal 29 Juli 2010 pada www.google.com/. 
Gafur Mohammad Zain A., 2011. Inkonsistensi Penerapan Good Governance Dalam Implementasi Kebijakan Alokasi Dana Desa. Program Studi Magister Administrasi Publik Universitas Gadjah Mada Yogyakarta.

Halim, Abdul dan Syukriy Abdullah. 2010. Hubungan dan Masalah Keagenan di Pemerintah Daerah: Sebuah Peluang Penelitian Anggaran dan Akuntansi, Jurnal Akuntansi Pemerintahan. Diakses tangal 29 juli 2010 pada http://bppk.depkeu.go.idl.

Hastuti Elgia., 2013. Akuntabilitas Pemerintah Desa Dalam Pengelolaan Anggaran Pendapatan dan Belanja Desa (APBDes) Pada Desa Sareng Kecamatan Geger Kabupaten Madiun. Skripsi S1 Fakultas Ekonomi dan Bisnis Universitas Negeri Surabaya.

Kuncoro Mudrajad., 2009. Metode Riset untuk Bisnis dan Ekonomi. Edisi ketiga. Yogyakarta: Erlangga. Skripsi S1 Fakultas Ilmu Administrasi Universitas Brawijaya Malang.

Kurrohman Taufiq., 2015. Accountability of Planning on Village Fund Allocation in osing community in Banyuwangi. International Conference on Accounting Studies (ICAS) Universiti Utara Malaysia.

Komite Standar Akuntansi Pemerintahan (KSAP) Nomor XX Akuntansi Berbasis Accrual. 2014.

Mahfudz., 2013. Analisis Dampak Alokasi Dana Desa (ADD) Terhadap Pemberdayaan Masyarakat dan Kelembagaan Desa. Universitas Diponegoro Semarang.

Mubarak, Zaki., 2010. Evaluasi Pemberdayaan Masyarakat Di Tinjau Dari Proses Pengembangan Kapasitas Pada Kegiatan PNPM Mandiri Perkotaan Desa Sastrodirjan Kabupaten Pekalongan. Tesis Program Magister Universitas Diponegoro.

Moh. Mahsun, Firma, Heribertus., 2015. Akuntansi Sektor Publik. Edisi Ketiga. Yogyakarta: Penerbit BPFE.

Ompi A. Wulan., 2013. Implementasi Kebijakan Alokasi Dana Desa (ADD) Dalam Meningkatkan Pembangunan Desa (Studi Di Desa Pangu Kecamatan Ratahan Kabupaten Minahasa Tenggara). Fakultas Ekonomi dan Bisnis Universitas Sam Ratulangi Manado.

Preeyanon, Antika., 2007. The Village Fund Project And Changes in the Dynamics of Local Power in Rural Thailand. University Of Leeds.

Putra C. Kusuma., 2013. Alokasi Dana Desa Dalam Pemberdayaan Masyarakat Desa (Studi Kasus Desa Wonorejo Kecamatan Singosari Kabupaten Malang). Universitas Brawijaya Malang.

Republik Indonesia. 2014. Undang-Undang Nomor 6 Tahun 2014 Tentang Desa. Jakarta.

Republik Indonesia. 2014. Peraturan Pemerintah Nomor 60 Tahun 2014 Tentang Dana Desa. Jakarta.

Republik Indonesia. 2015. Peraturan Pemerintah Nomor 47 Tahun 2015 Tentang Perubahan Atas Peraturan Pemerintah Nomor 43 Tahun 2014 Tentang Peraturan Pelaksanaan Undang-undang Nomor 6 Tahun 2014 Tentang Desa. Jakarta.

Republik Indonesia. 2015. Peraturan Menteri Desa Nomor 5 Tahun 2015 Tentang Penetapan Prioritas Penggunaan Dana Desa. Jakarta.

Republik Indonesia. 2015. Keputusan Bersama Menteri Dalam Negeri, Menteri Keuangan, dan Menteri Desa, Pembangunan Daerah Tertinggal dan Transmigrasi No.49 Tahun 2015 Tentang Percepatan Penyaluran, Pengelolaan, dan Penggunan Dana Desa Tahun 2015. Jakarta.

Republik Indonesia. 2015. Peraturan Presiden No.36 Tahun 2015 Tentang Rincian Anggaran Pendapatan dan Belanja Negara Tahun Anggaran. Jakarta. http://www.kemendikbud.go.id/main/blog/2016/04/sektor-infrastruktur-prioritaspenggunaan-dana-desa-2016 
Peraturan Bupati Kepulauan Yapen No.04 Tahun 2015 Tentang Tata Cara Pembagian dan Penetapan Rincian Dana Kampung Pada Setiap Kampung di Kabupaten Kepulauan Yapen Tahun Anggaran 2015.

Peraturan Bupati No.24 tahun 2015 Tentang Tugas Pokok, Fungsi dan Tata Kerja Badan Pemberdayaan Masyarakat Kampung dan Transmigrasi Kepulauan Yapen, Papua.

Grestanti., 2016. Analisis Penerapan Pengelolaan Keuangan Pada Alokasi Dana Desa Di Kecamatan Wates Kabupaten Kediri. Universitas Airlangga Surabaya.

Subroto Agus., 2009. Akuntabilitas Pengelolaan Dana Desa Pada Kecamatan Tlogomulyo Kabupaten Temanggung. Tesis Program Studi Magister Sains Akuntansi Universitas Diponegoro Semarang.

Sudarsono,dkk. 2014. Teori Administrasi. Tanggerang Selatan: Penerbit Universitas Terbuka. Sujarweni V. Wiratna., 2015. Akuntansi Sektor Publik. Yogyakarta: Pustaka Baru Press.

Warsono Hardi, Ruksamin., 2014. The Obstacles of Implementation of Village Allocation Fund Program in the North Konawe Southeast Sulawesi. Published by Canadian Center of Science and Education.

Widyaningsih E. Yuli., 2012. Penerapan Analisis Hirarki Proses (AHP): Dalam Penentuan Formula Alokasi Dana Desa Di Kabupaten Sragen. Tesis Program Studi Magister Ekonomi dan Pembangunan Universitas Sebelas Maret.

Wisakti Daru., 2008. Implementasi Alokasi Dana Desa Di Wilayah Kecamatan Geyer Kabupaten Grobogan. Tesis Program Studi Magister Ilmu Administrasi Universitas Diponegoro.

Zheng, Xian., 2012. Why Rural Households Choose not to Participate in the Open and Optional Village Development Fund in the Poverty Stricken Areas oSf China. Institutionen For Ekonomi Swedish University. 